\title{
Synthesis of Carbo[6]Helicene Derivatives Grafted with Amino or Aminoester Substituents from Enantiopure [6]Helicenyl Boronates
}

\author{
Nora Hellou, ${ }^{\dagger}$ Aurélie Macé,${ }^{\dagger}$ Clothilde Martin, ${ }^{\dagger}$ Vincent Dorcet, ${ }^{\dagger}$ Thierry Roisnel,${ }^{\dagger}$ Marion Jean,${ }^{\ddagger}$ Nicolas Vanthuyne,${ }^{\ddagger}$ Fabienne \\ Berrée ${ }^{\dagger}$ Bertrand Carboni, ${ }^{*}, \dagger$ Jeanne Crassous, ${ }^{*}, \dagger$ \\ †Université de Rennes 1, Institut des Sciences Chimiques de Rennes, UMR CNRS 6226 Campus de Beaulieu, 35042, Rennes Cedex,
} France. ${ }^{*}$ Aix Marseille Univ, CNRS, Centrale Marseille, iSm2, Marseille, France.

E-mail: bertrand.carboni@univ-rennesl.fr; jeanne.crassous@univ-rennesl.fr

RECEIVED DATE (will be automatically inserted after manuscript is accepted).

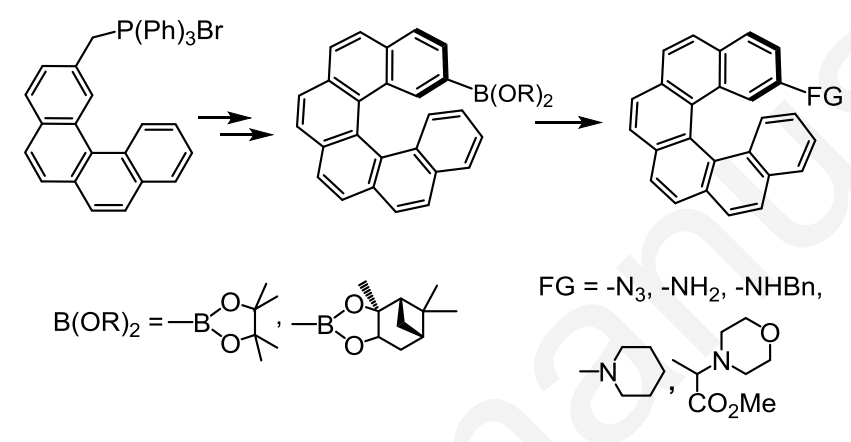

ABSTRACT. Enantiopure carbo[6]helicenyl boronates were synthesized using a photocyclisation reaction as the key step. These compounds were further converted to various amino derivatives using copper-catalyzed azidation or amination and reductive alkylation of benzylazide by a helicenyl dichloroborane. Asymmetric Petasis condensation with glyoxylic acid and morpholine controlled by the helical chirality afforded the corresponding amino esters.

[n]Helicenes are composed of $\mathrm{n}$ ortho-fused aromatic or heteroaromatic rings that display inherent helical chirality. Indeed, when $\mathrm{n} \geq 5$, they become configurationally stable and can be obtained in enantiopure $(P)$ and $(M)$ forms by a diversity of methods. ${ }^{1}$ Due to their unique screw shape and extended $\pi$-conjugation, helicenes display strong chiroptical properties (optical rotation values, circular dichroism and circularly polarized luminescence). ${ }^{1}$ In the last decade, there has been a growing interest to use helicenes or analogues as building blocks for the design of chiral ligands for asymmetric catalysis, ${ }^{2}$ materials for opto-electronics, ${ }^{3}$ chiral sensors ${ }^{4}$ or chiroptical switches. ${ }^{5}$ In this context, the development of efficient strategies to tune the chiroptical properties of helicene-based derivatives by varying their structure remains of prime importance. Although a great number of organic helicenes have been synthesized, ${ }^{1}$ simple amino derivatives still remain rather difficult to access. For example, only few helicenyl primary amines have been hitherto described in the literature (see 1-6, Figure 1), although such compounds constitute key building blocks for further functionalization or for studying supramolecular assembly of $\pi$-helical systems. ${ }^{6,7}$ 

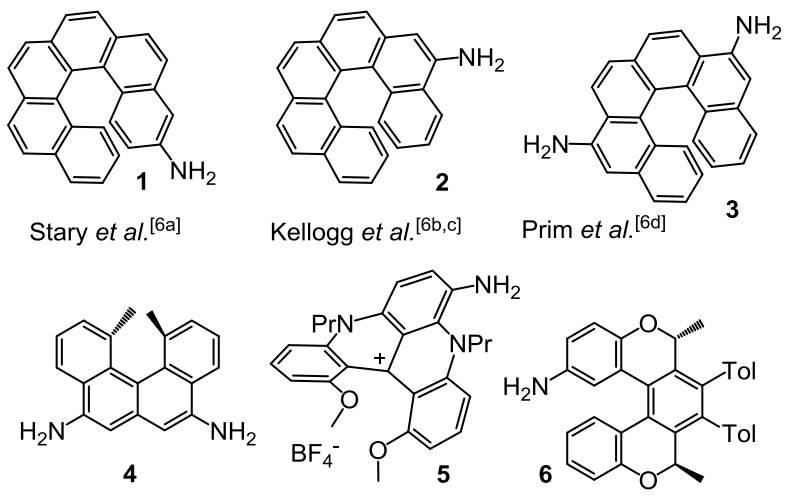

Yamaguchi et al. ${ }^{[6]}$

Lacour et al. ${ }^{[6 f]}$

Stary et al. ${ }^{[6 \mathrm{~g}]}$

Figure 1. Helicenyl primary amines described in the literature.

Most common methods introduce the amine functionality in a final stage via, for example, coupling of a bromohelicene, ${ }^{6 \mathrm{ff}} \mathrm{h}$ reduction of a nitro derivative, ${ }^{6 \mathrm{~b}}$ or Curtius rearrangement of a carboxylic acid. ${ }^{6 \mathrm{~g}}$ To our knowledge, none of them took advantage of the presence of boron, even though it can constitute a valuable source of a large variety of functional groups. ${ }^{6 c, 6 e, 8,9}$

In this manuscript, we report a straightforward access to enantiopure 2-carbo[6]helicene boronates $\mathbf{1 0}$ that are appealing precursors of the corresponding amino and aminoacid derivatives 12-15 (Schemes 1 and 2).

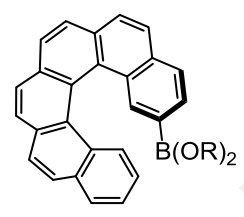

10

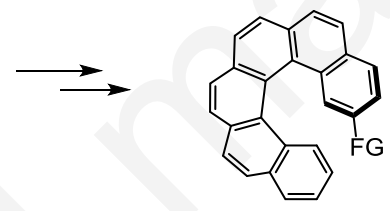

$12 \quad \mathrm{FG}=-\mathrm{NH}_{2}$

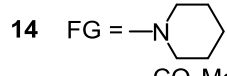

$13 \mathrm{FG}=-\mathrm{NHBn}$

Scheme 1. Synthesis of $(M)$-amino- and aminoester substituted [6]helicenes 12, 13, 14 and 15.

Racemic carbo[6]helicene ( \pm )-10a bearing a pinacol boronic ester was first prepared in two steps (Scheme 2), i.e. by a Wittig reaction of 2-benzo[c]phenanthrylmethyl-phosphonium bromide $7^{10 \mathrm{c}}$ with pinacol 4 -formyl-phenylboronate 8a ${ }^{11}$ (stereoselectivity $Z / E=80 / 20$ ), followed by a photocyclization reaction using stoechiometric quantities of iodine and a large excess of propylene oxide, under high dilution conditions and using an immersion $150 \mathrm{~W} \mathrm{Hg} \mathrm{lamp.} \mathrm{This} \mathrm{approach} \mathrm{enables} \mathrm{to}$ install the boronate moiety at the 2-position from the beginning of the synthesis, which proved its compatibility with the irradiation conditions. ${ }^{12}$
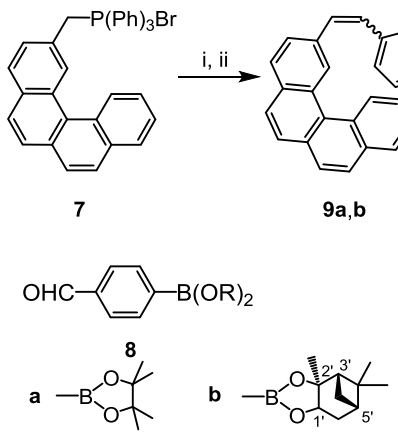

$9 a, b$
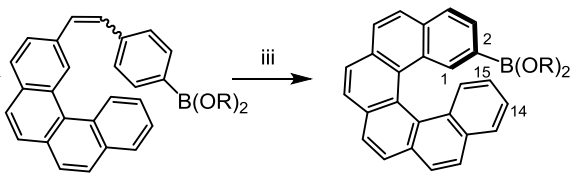

$10 \mathrm{a}, \mathrm{b}$

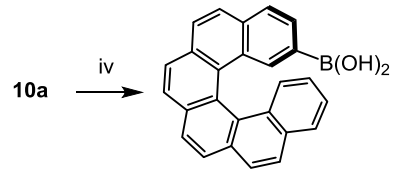

$10 \mathrm{c}$

Scheme 2. Preparation of carbo[6]helicene-2-boronic pinacol ester ( \pm )-10a and carbo[6]helicene-2-boronic pinanediol ester 10b. Reagents and conditions: i) 8a or $8 \mathbf{b}, n$-BuLi, THF, $-78^{\circ} \mathrm{C}$; ii) rt, $3 \mathrm{hrs,} 9 \mathbf{a}, 70 \%(Z / E=80 / 20)$ and $\mathbf{9 b} 89 \%(Z / E=65 / 35)$; iii) $h v, 1$ eq. $\mathrm{I}_{2}, 40$ eq. propylene oxide, toluene, $15 \mathrm{hrs,} \mathbf{1 0 a}$, $70 \%$ and $\mathbf{1 0 b} 63 \%$; iv) $\mathrm{NaIO}_{4}, \mathrm{NH}_{4} \mathrm{OAc}$, acetone/water (2/1), rt, $4 \mathrm{~d}, 84 \%$ from ( \pm )-10a. 
Helicenyl boronate $( \pm)-\mathbf{1 0 a}$ was fully characterized by NMR and mass spectrometry. For instance, its ${ }^{1} \mathrm{H}$ NMR spectrum showed two signals at 1.21 and $1.22 \mathrm{ppm}$ corresponding to the four diastereotopic methyl groups of the pinacol moiety and two doublets of doublet of doublet at 6.65 and 7.19 ppm for protons H-15 and H-14, respectively (see Supporting Information, SI). A characteristic signal was observed at $31.1 \mathrm{ppm}$ in ${ }^{11} \mathrm{~B}$ NMR. The conversion into the corresponding boronic acid 10c was cleanly achieved in a $84 \%$ yield by treatment with sodium periodate in an acetone/water mixture. ${ }^{13}$ The pure $(P)$ - and $(M)$ - enantiomers of 10a (with respective $e e^{\prime}$ s $>99.5 \%$ ) were obtained by using HPLC separation over a chiral stationary phase (see SI). The chiroptical properties (electronic circular dichroism (ECD), specific and molar rotations $(\mathrm{MR}))^{14}$ of $(P)$ - and $(M)$-10a were then examined. The two mirror-image ECD spectra in $\mathrm{CH}_{2} \mathrm{Cl}_{2}$ solutions are depicted in Figure 2. They display the classical ECD signature for [6] helicene derivative, i.e. for $(P)-\mathbf{1 0 a}$, the strong negative band at $250 \mathrm{~nm}\left(\Delta \varepsilon=-280 \mathrm{M}^{-1} \mathrm{~cm}^{-1}\right)$ and a strong positive one at $330 \mathrm{~nm}\left(\Delta \varepsilon=+307 \mathrm{M}^{-1} \mathrm{~cm}^{-1}\right)$, with a clear vibronic structure. This ECD is comparable to carbo[6]helicenes. ${ }^{10 \mathrm{a}, \mathrm{c}}$ The specific and molar rotations ${ }^{14}$ are high $\left((P)-(+)-\mathbf{1 0 a}:[\alpha]_{D}^{23}=+2600,[\phi]_{D}^{23}=\right.$ $+11800( \pm 7 \%),(M)-(-)-10 a:[\alpha]_{D}^{23}=-2800,[\phi]_{D}^{23}=-12700\left( \pm 7 \%, C 210^{-4} \mathrm{M}, \mathrm{CH}_{2} \mathrm{Cl}_{2}\right)$ and again of similar magnitude compared to carbo[6]helicene $\left((M)\right.$ enantiomer: $[\alpha]_{D}=-3860,[\phi]_{D}=-11950\left(C 10^{-3} \mathrm{M}, \mathrm{CHCl}_{3}\right){ }^{10 \mathrm{~b}}$
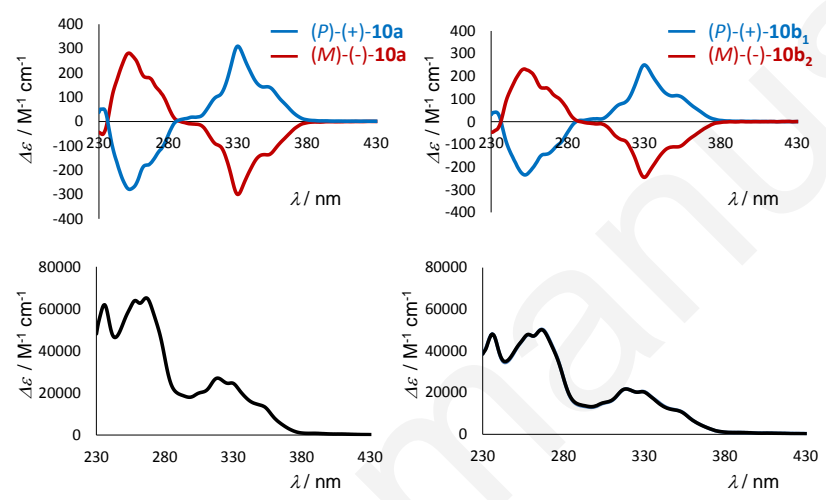

Figure 2. UV-vis and ECD spectra of enantiomers $(P)-(+)$ and $(M)-(-)-\mathbf{1 0 a}$ and of diastereomers $\left(P, 1^{\prime} S, 2^{\prime} S, 3^{\prime} R, 5^{\prime} S\right)-\mathbf{1 0 b}_{\mathbf{1}}$ and $\left(M, 1^{\prime} S, 2^{\prime} S, 3^{\prime} R, 5^{\prime} S\right)-\mathbf{1 0 b}_{\mathbf{2}}(C$ $5.10^{-5} \mathrm{M}$ in $\mathrm{CH}_{2} \mathrm{Cl}_{2}$ ).

Similarly to $\mathbf{1 0 a}$, but using $(1 S, 2 S, 3 R, 5 S)$ pinanediol 4-formylphenylboronate $\mathbf{8} \mathbf{b}^{11}$ as starting aldehyde and following the same Wittig/photocyclization sequence as described above, was prepared the 2-carbo[6]helicenyl pinanediol boronate 10b. Unfortunately, no asymmetric induction was observed in this process and a $1 / 1$ diastereomeric mixture of $\left(P, 1^{\prime} S, 2^{\prime} S, 3^{\prime} R, 5^{\prime} S\right)$ $\mathbf{1 0 b _ { 1 }}$ and $\left(M, 1^{\prime} S, 2^{\prime} S, 3^{\prime} R, 5^{\prime} S\right) \mathbf{1 0 \mathbf { b } _ { 2 }}$ was obtained in a $63 \%$ overall yield. This lack of asymmetric induction could be due to the uncontrolled rotation around the carbon-boron bond which prevents the differentiation of both sides of the trigonal boron atom. The two pure diastereomers were isolated by HPLC (with respective $d e$ 's $>99.5 \%$ ) and characterized by NMR and mass spectrometry. Their ${ }^{1} \mathrm{H}$ NMR spectra showed the typical signals for both the hexahelicene part and for the pinanyl moiety. As described in Figure 2, they display mirror-image relationship, since the pinanediol boronate unit has no ECD response in the UV-vis domain, and similar signature as for 10a enantiomers, although with a lower intensity. Their specific and molar rotations are also almost mirror-image (for instance, $(P)-(+)-\mathbf{1 0 b _ { 1 }}:[\alpha]_{D}^{23}=+2370,[\phi]_{D}^{23}=+11990,(M)-(-)-10 b_{2}:[\alpha]_{D}^{23}=$ $\left.-2640,[\phi]_{D}^{23}=-13360\left( \pm 7 \%, C 10^{-4} \mathrm{M}, \mathrm{CH}_{2} \mathrm{Cl}_{2}\right)\right)$, again with low influence of the grafted pinanediol boronate.

Apart from column chromatographic separations, ${ }^{1,15 a, g}$ the few reported preparations of enantiopure helicene derivatives are essentially based on asymmetric catalysis, ${ }^{15 \mathrm{c}, \mathrm{d}}$ kinetic resolution, ${ }^{15 \mathrm{f}}$ enantio- ${ }^{15 \mathrm{~b}}$ or diastereoselective syntheses. ${ }^{9 \mathrm{c}, 15 \mathrm{e}}$ Furthermore, although the parent carbo[n]helicenes have been known to form conglomerates, ${ }^{16 a}$ resolution of helicene enantiomers by crystallization methods has still been rarely used. ${ }^{16}$ In the course of this work, we serendipitously observed that the two diastereomers $\mathbf{1 0 b _ { 1 }}$ and $\mathbf{1 0 b _ { 2 }}$ displayed very different solubilities in $\mathrm{MeOH}$, with the pure diastereomer $\left(P, 1^{\prime} S, 2^{\prime} S, 3^{\prime} R, 5^{\prime} S\right)-10 b_{1}$ crystallizing out of the solution in $23 \%$ yield (a diastereomeric excess of $\sim 23 \%$ in favour of $\left(M, 1^{\prime} S, 2 ' S, 3^{\prime} R, 5^{\prime} S\right)-\mathbf{1 0 b _ { 2 }}$ was found for the solution).

Single crystals of $(M)$-10a and the less soluble diastereomer $(P)-\mathbf{1 0 b} \mathbf{b}_{\mathbf{1}}$ were then grown from a saturated solution in $\mathrm{MeOH}$. The X-ray crystallography ascertained their structure and stereochemistry (see Figure 3). ${ }^{17}$ For example, 10b1 crystallized in the $P 2_{1} 2_{1} 2_{1}$ space group, the helicene unit displaying a helicity (dihedral angle between the terminal rings) of $52.10^{\circ}$, which is typical for organic helicenes, ${ }^{1}$ and the B-C bond showing a regular length of $1.56 \AA{ }^{8 a}$ Note also that the boronate cycle deviates from coplanarity with the terminal phenyl ring by $20.02^{\circ}$. Finally, from view b in Figure 3 , one can see that in the solid state the bulky part of the pinanediol unit is directed towards the helical core. 

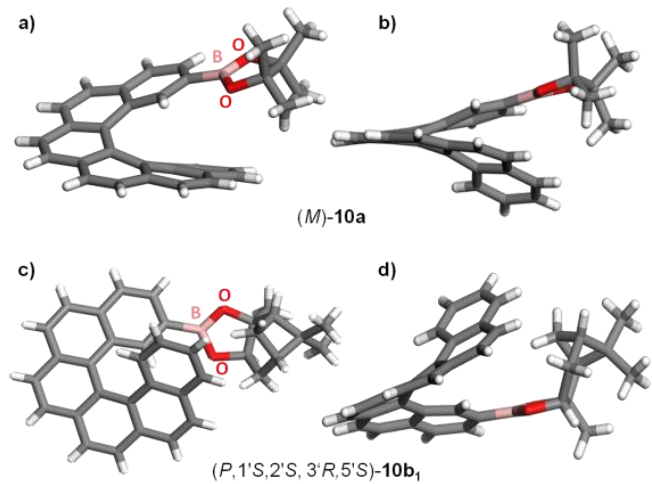

Figure 3. Two views of the X-ray crystallographic structures of $(M)-\mathbf{1 0 a}$ (views $\mathbf{a}$ and $\mathbf{b}$ ) and $\left(P, 1^{\prime} S, 2^{\prime} S, 3^{\prime} R, 5^{\prime} S\right)-\mathbf{1 0 b}_{\mathbf{1}}$ (views $\mathbf{c}$ and $\mathbf{d}$ )

Having the enantiopure boronates $(P)$ - and $(M)-\mathbf{1 0 a}$ in hands, we then turned our attention to their conversion to the corresponding amino and aminoacid derivatives 12-15 (Scheme 3). First attempts to directly introduce a $\mathrm{NH}_{2}$ group from the boronic ester group by reaction with $\mathrm{H}_{2} \mathrm{~N}-\mathrm{OSO}_{3} \mathrm{H}^{18}$ or $\mathrm{MeONH}_{2}{ }^{19}$ gave poor yields and irreproducible results that led us to envisage a two-step sequence. According to a reported procedure, ${ }^{20}$ copper-catalyzed azidation of $(M)$-10a was carried out with copper sulfate in methanol at reflux for $19 \mathrm{~h}$. The resulting azide $(M)-\mathbf{1 1}$, which could be isolated, but with a poor yield, was directly engaged in a hydrogenation step with $\mathrm{H}_{2}$ in the presence of $\mathrm{Pd} / \mathrm{C}$ to give $(M)-\mathbf{1 2}$ in an overall $75 \%$ yield. Note that the enantiomerically pure diastereomer $\left(P, 1^{\prime} S, 2^{\prime} S, 3^{\prime} R, 5^{\prime} S\right)-\mathbf{1 0 b _ { 1 }}$ was also successfully transformed to $(P)-12$ using the same method, thus illustrating the possibility of straightforwardly preparing enantiopure 2-amino-helicene through a photocyclization-crystallization (vide supra)-amination, a process that can be particularly appealing for large-scale synthetic processes such as flow photochemistry. ${ }^{10 \mathrm{~b}}$

The secondary $N$-benzyl helicenyl amine $(M)$-13 was prepared from $(M)$-10a via conversion to the corresponding dichloroborane and then, without isolation of this sensitive intermediate, treatment with benzyl azide. ${ }^{21}$ The formation of the piperidino derivative $(M)$-14 was achieved in a moderate yield (44\%) via a Chan-Lam amination using recently optimized reactions with copper acetate as catalyst and boric acid as additive. ${ }^{22}$ The $(P)$ enantiomers of 12 and 14 were also synthesized according to the same procedures. Finally, the transformation of $(M)-\mathbf{1 0 a}$ to an amino ester derivative $\mathbf{1 5}$ was carried out via a three-component Petasis reaction with glyoxylic acid and morpholine, followed by esterification with (trimethylsilyl)diazomethane. ${ }^{23}$ This condensation produced two diastereomeric compounds $\mathbf{1 5 a}, \mathbf{b}$ with a modest stereocontrol ( $d r: 7 / 3$, measured by ${ }^{1} \mathrm{H}$ NMR of the crude mixture), which constitutes to our knowledge the first example of asymmetric induction controlled by the helicity of the aryl partner in this type of reaction. The structure of the minor isomer 15b was ascertained by X-ray diffraction analysis (Figure 4). ${ }^{17}$

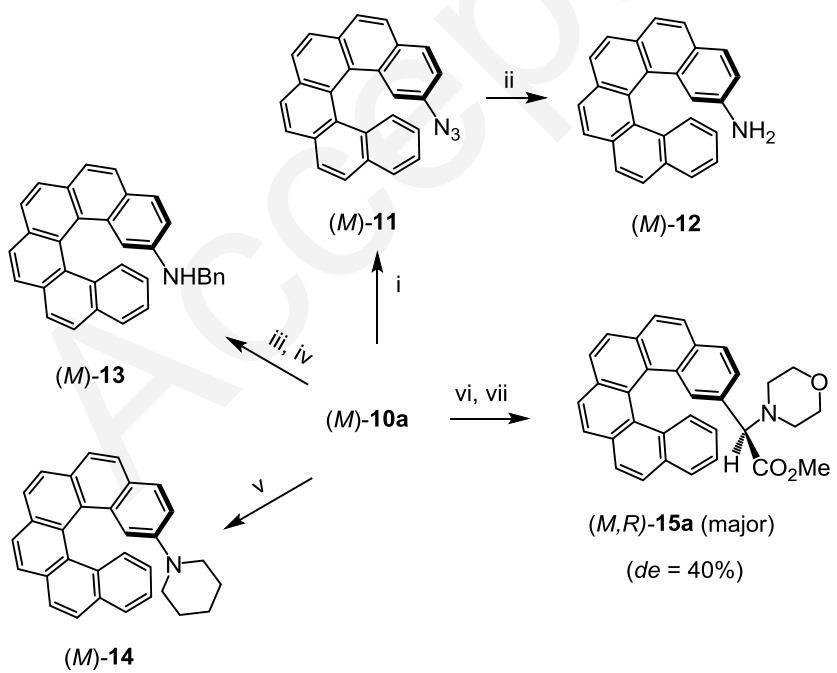

Scheme 3. Synthesis of $(M)$-helicenyl derivatives 12-15 from helicene-boronate $(M)$-10a. Reagents and conditions: i) $\mathrm{NaN}_{3}, \mathrm{CuSO}_{4} \cdot 5 \mathrm{H}_{2} \mathrm{O}, \mathrm{MeOH}$, reflux, 19h; ii) $\mathrm{H}_{2}$ (1 atm), $10 \% \mathrm{Pd} / \mathrm{C}$, EtOAc, rt, 21h, 75\% (2 steps); iii) $\mathrm{BCl}_{3}, \mathrm{CH}_{2} \mathrm{Cl}_{2}$, rt, 3h; iv) $\mathrm{PhCH}_{2} \mathrm{~N}_{3}, \mathrm{CH}_{2} \mathrm{Cl} 2, \mathrm{rt}, 17 \mathrm{~h}, 68 \%$ (two steps); v) Cu(OAc) 2 , $\mathrm{B}(\mathrm{OH})_{3}$, piperidine, $\mathrm{MeCN}, 80{ }^{\circ} \mathrm{C}, 26 \mathrm{~h}, 44 \%$; vi) morpholine, glyoxylic acid monohydrate, 1,1,1,3,3,3-hexafluoro-2-propanol, 60 ${ }^{\circ} \mathrm{C}$, 48h; vii) (trimethylsilyl)diazomethane in diethyl ether, THF/MeOH, rt, 20h, 84\% (two steps). 


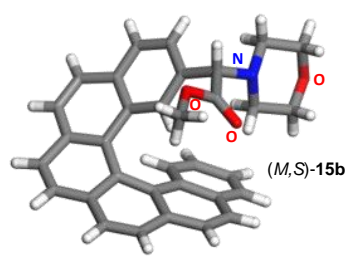

Figure 4. X-ray crystallographic structure of $(M, S)$-15b (minor isomer).

The UV-vis and ECD spectra of the new enantiopure compounds synthesized are depicted in Figure 5. It can be seen that the primary, secondary and tertiary amino-derivatives show very similar UV-vis and ECD spectra, with for example two absorption bands around 245 and $265 \mathrm{~nm}$ that are positively ECD-active $\left(\Delta \varepsilon \sim+115\right.$ and $\left.+75 \mathrm{M}^{-1} \mathrm{~cm}^{-1}\right)$ and two other ones around 325 and $350 \mathrm{~nm}$ that are negatively ECD-active $\left(\Delta \varepsilon \sim-100\right.$ and $\left.-75 \mathrm{M}^{-1} \mathrm{~cm}^{-1}\right)$ for the $(M)-(-)-12$ and $(M)-(-)-14$ enantiomers. As for the diastereomeric amino-ester grafted $(M)$-helicenes 15a and 15b, they display very similar UV-vis and ECD spectra that appeared much stronger than the amino-grafted ones, with a strong band around $250 \mathrm{~nm}\left(\varepsilon>5010^{3} \mathrm{M}^{-1}\right.$ $\mathrm{cm}^{-1}, \Delta \varepsilon \sim+245$ to $\left.+275 \mathrm{M}^{-1} \mathrm{~cm}^{-1}\right)$ and several strong ones between $300-400 \mathrm{~nm}\left(\varepsilon>2010^{3} \mathrm{M}^{-1} \mathrm{~cm}^{-1}, \Delta \varepsilon \sim-315\right.$ to $-77 \mathrm{M}^{-1}$ $\left.\mathrm{cm}^{-1}\right)$.

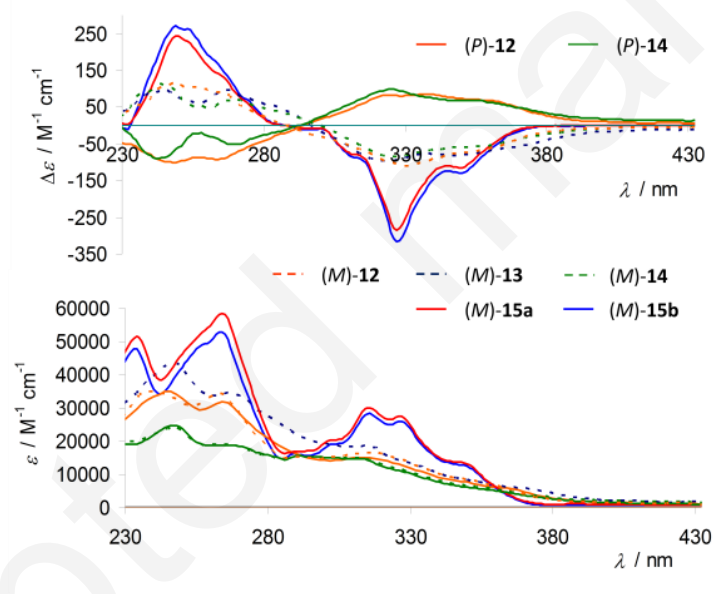

Figure 5. UV-vis and ECD spectra of enantiomers $(P)$ and $(M)-\mathbf{1 2},(M)-\mathbf{1 3},(P)$ and $(M)-\mathbf{1 4}$ and the two enantiopure diastereomers $(M)$-15a and $(M)$-15b $(C$ $\sim 5.10^{-5} \mathrm{M}$ in $\mathrm{CH}_{2} \mathrm{Cl}_{2}$ ).

In summary, we have developed a straightforward set of reactions based on photocyclisation as key step that allow the efficient synthesis of enantiopure carbo[6]helicenyl boronates. These compounds are convenient precursors of several amino and aminoacid derivatives via chemical transformation of the boronic ester moiety. Compared to other multi-step processes described in the literature, ${ }^{6}$ this strategy appears short and very simple. Application of this chemistry to other functionalized helicenes and development of these new organoboranes are in progress in our groups.

\section{EXPERIMENTAL SECTION}

Solvents were freshly distilled under argon from sodium / benzophenone (THF) or from phosphorus pentoxide $\left(\mathrm{CH}_{2} \mathrm{Cl}_{2}=\right.$ DCM). All commercially available chemicals were used without further purification. Column chromatography purifications were performed over silica gel (Merck Geduran 60, 0.063-0.200 mm). Flash chromatography purifications were performed on a Grace Reveleris ${ }^{\mathrm{TM}}$ with Puriflash ${ }^{\mathrm{TM}} 15 \mu \mathrm{m}$ flash cartridges (Interchim). Irradiation reactions were conducted using a Heraeus TQ 150 mercury vapor lamp. NMR spectra were recorded at room temperature on a Bruker AV III $300 \mathrm{MHz}$ spectrometer, a Bruker AV III $400 \mathrm{MHz}$ equipped with a tunable BBFO probe, a Bruker Av III HD $500 \mathrm{MHz}$ fitted with a tunable BBO probe (Biosit platform, Université de Rennes 1). ${ }^{1} \mathrm{H}$ and ${ }^{13} \mathrm{C}$ chemical shifts are reported in parts per million (ppm) relative to $\mathrm{Me}_{4} \mathrm{Si}$ as external standard. Mass spectrometry was performed by the CRMPO, University of Rennes 1, on 
a LC-MS Agilent 6510 or a Thermo Fisher Q-Exactive using ESI technique. Melting points were measured on a melting point apparatus Stuart SMP10. Specific rotations (in $\mathrm{deg} \mathrm{cm}^{3} \mathrm{~g}^{-1}$ ) were measured in a $1 \mathrm{dm}$ thermostated quartz cell on a Perkin Elmer-341 polarimeter. Circular dichroism (in $\mathrm{M}^{-1} \mathrm{~cm}^{-1}$ ) was measured on a Jasco J-815 Circular Dichroism Spectrometer IFR140 facility (Biosit platform, Université de Rennes 1). UV/vis spectroscopy was conducted on a Varian Cary 5000 spectrometer. Chiral high-performance liquid chromatography (HPLC) was performed by iSm2, Aix Marseille University, on an Agilent Technologies 1260 Infinity with Igloo-Cil ovens, using Jasco OR-1590 and CD-2095 as polarimetric and circular dichroïsm detectors. The analytical $(250 \times 4.6 \mathrm{~mm})$ and preparative $(250 \times 10 \mathrm{~mm}) \mathrm{columns}$ used are $(S, S)$-Whelk-O1 from Regis Technologies (Morton Grove, USA), Chiralpak IA, and Chiralpak IB.

2-Benzo[c]phenanthrylmethylphosphonium bromide $\mathbf{7},{ }^{10 c} p$-benzaldehyde pinacol boronate 8a and $p$-benzaldehyde pinanediol boronate $\mathbf{8 b}$ were prepared according to the literature. ${ }^{11}$

\section{General procedure for 2-carbo[6]helicene pinacol and pinanediol boronates 10.}

Synthesis of 2-styrylbenzo[c]phenanthrenes (9). A suspension of 2-benzo[c]phenanthrylmethylphosphonium bromide 7 (375 $\mathrm{mg}, 0.64 \mathrm{mmol}, 1$ eq.) in $18 \mathrm{~mL}$ of anhydrous THF, under argon, was cooled to $-78^{\circ} \mathrm{C}$. To the stirred suspension was added dropwise $n$-BuLi (2.5 M in hexanes, $0.26 \mathrm{ml}, 0.64 \mathrm{mmol}, 1$ eq.). The reaction mixture turned deep red and then slowly was warmed up to room temperature. Stirring was continued further for $45 \mathrm{~min}$ and, after cooling to $-78{ }^{\circ} \mathrm{C}$, was added dropwise a solution of the boronate $\mathbf{8 a}$ or $\mathbf{8 b}(0.61 \mathrm{mmol}, 0.95$ eq. $)$ in $1 \mathrm{~mL}$ of THF. The reaction mixture was warmed up to room temperature and stirring was maintained for $3 \mathrm{~h}$, while the solution turns yellow. $10 \mathrm{~mL}$ of pentane were added and the reaction mixture was filtered over Celite ${ }^{\circledR}$ and concentrated under vacuum. The crude oily product was purified by column chromatography on silica gel.

Pinacol (4-(2-(benzo[c]phenanthren-2-yl)vinyl)phenyl) boronic ester $(Z / E=80 / 20)(9 a) .206 \mathrm{mg}$, 70\%. Yellowish solid, mp = 62-64 ${ }^{\circ} \mathrm{C}, \mathrm{R}_{\mathrm{f}}=0.75$ and 0.70 (cyclohexane/ $\left.\mathrm{CH}_{2} \mathrm{Cl}_{2}, 2 / 8\right)$. (Z)-isomer, ${ }^{1} \mathrm{H} \mathrm{NMR}\left(300 \mathrm{MHz}, \mathrm{CDCl}_{3}\right)$ : ${ }^{1} \mathrm{H} \mathrm{NMR}(300 \mathrm{MHz}$, $\left.\mathrm{CDCl}_{3}\right) \delta 8.96(\mathrm{~s}, 1 \mathrm{H}), 8.42(\mathrm{~d}, J=8.5 \mathrm{~Hz}, 1 \mathrm{H}), 7.98(\mathrm{dd}, J=8.0,1.5 \mathrm{~Hz}, 1 \mathrm{H}), 7.95-7.27(\mathrm{~m}, 12 \mathrm{H}), 6.95(\mathrm{~d}, J=12.1 \mathrm{~Hz}, 1 \mathrm{H})$, $6.83(\mathrm{~d}, J=12.1 \mathrm{~Hz}, 1 \mathrm{H}), 1.37(\mathrm{~s}, 12 \mathrm{H}) .{ }^{13} \mathrm{C} \mathrm{NMR}\left(75 \mathrm{MHz}, \mathrm{CDCl}_{3}\right) \delta 140.5,135.2,133.5,132.6,131.8,131.3,130.9$, $130.5,130.3,128.7,128.6,128.4,127.7,127.6,127.3,127.0,126.9,126.8,126.4,125.8,83.9,25.0 .{ }^{11} \mathrm{~B} \mathrm{NMR}(96 \mathrm{MHz}$, $\left.\mathrm{CDCl}_{3}\right) \delta$ 31.0. HRMS (ESI) $[\mathrm{M}+\mathrm{Na}]^{+}$calculated for $\mathrm{C}_{32} \mathrm{H}_{29} \mathrm{O}_{2} \mathrm{BNa} 479.2158$, found 479.2151 .

$\left(1 S^{\prime}, 2 S^{\prime}, 3 R^{\prime}, 5 S^{\prime}\right)$ Pinanediol (4-(2-(benzo[c]phenanthren-2-yl)vinyl)phenyl) boronic ester (Z/E=65/35) (9b). $290 \mathrm{mg}, 89 \%$. Yellowish solid. $\mathrm{R}_{\mathrm{f}}=0.95\left(\mathrm{CH}_{2} \mathrm{Cl}_{2}\right)$. (Z)-isomer, ${ }^{1} \mathrm{H}$ NMR $\left(300 \mathrm{MHz}, \mathrm{CD}_{2} \mathrm{Cl}_{2}\right) \delta 8.92(\mathrm{~s}, 1 \mathrm{H}), 8.35(\mathrm{~d}, \mathrm{~J}=8.5 \mathrm{~Hz}, 1 \mathrm{H}), 8.03$ $(\mathrm{t}, \mathrm{J}=8.3 \mathrm{~Hz}, 1 \mathrm{H}), 7.95-7.27(\mathrm{~m}, 12 \mathrm{H}), 6.91(\mathrm{~d}, \mathrm{~J}=11.9 \mathrm{~Hz}, 1 \mathrm{H}), 6.79(\mathrm{~d}, \mathrm{~J}=12.2 \mathrm{~Hz}, 1 \mathrm{H}), 4.43(\mathrm{dd}, \mathrm{J}=8.8,1.4 \mathrm{~Hz}, 1 \mathrm{H})$, $1.46(\mathrm{~s}, 3 \mathrm{H}), 1.30(\mathrm{~s}, 3 \mathrm{H}), 1.18(\mathrm{~d}, \mathrm{~J}=10.7 \mathrm{~Hz}, 1 \mathrm{H}), 0.88(\mathrm{~s}, 3 \mathrm{H})$.

Synthesis of helicenylboronate (10). Boronate 9 (0.39 mmol, 1 eq.) (Z/E mixture), iodine (100 mg, $0.39 \mathrm{mmol}, 1 \mathrm{eq}$.$) and$ propylene oxide $(1,1 \mathrm{~mL}, 15.6 \mathrm{mmol}, 40$ eq.) were dissolved in toluene $(2.5 \mathrm{~L})$ previously degazed, and placed in a photoreactor equipped with an immersion lamp (150W). The mixture was irradiated for 22 hours. After evaporation of the solvent, the residue was purified by column chromatography on silica gel. The two pure enantiomers or diastereomers were then separated by using HPLC.

( \pm ) Pinacol hexahelicen-2-ylboronic ester (10a). $125 \mathrm{mg}, 70 \%$. Yellowish solid, $\mathrm{mp}=238-240{ }^{\circ} \mathrm{C} . \mathrm{R}_{\mathrm{f}}=0.10$ (cyclohexane/ $\left.\mathrm{CH}_{2} \mathrm{Cl}_{2}, 8 / 2\right) .{ }^{1} \mathrm{H}$ NMR $\left(300 \mathrm{MHz}, \mathrm{CDCl}_{3}\right) \delta 8.17(\mathrm{~s}, 1 \mathrm{H}), 8.04-7.87(\mathrm{~m}, 8 \mathrm{H}), 7.83(\mathrm{~d}, J=7.9 \mathrm{~Hz}, 1 \mathrm{H}), 7.77$ $(\mathrm{dd}, J=8.0,1.3 \mathrm{~Hz}, 1 \mathrm{H}), 7.61(\mathrm{dd}, J=7.9,1.1 \mathrm{~Hz}, 1 \mathrm{H}), 7.57(\mathrm{dd}, J=8.5,1.1 \mathrm{~Hz}, 1 \mathrm{H}), 7.19(\mathrm{ddd}, J=8.0,6.9,1.1 \mathrm{~Hz}, 1 \mathrm{H})$, $6.65(\mathrm{ddd}, J=8.5,6.9,1.3 \mathrm{~Hz}, 1 \mathrm{H}), 1.22(\mathrm{~s}, 6 \mathrm{H}), 1.21(\mathrm{~s}, 6 \mathrm{H}) .{ }^{13} \mathrm{C} \mathrm{NMR}\left(75 \mathrm{MHz}, \mathrm{CDCl}_{3}\right) \delta 136.1,133.7,133.2,132.2$, $131.5,131.2,130.3,129.9,129.0,128.4,128.3,127.9,127.8,127.73,127.72,127.51,127.48,127.2,127.0,126.9$, 126.6,

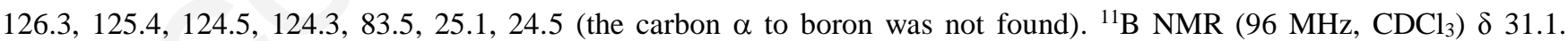
HRMS (ESI) $[\mathrm{M}+\mathrm{Na}]^{+}$calculated for $\mathrm{C}_{32} \mathrm{H}_{27} \mathrm{O}_{2} \mathrm{BNa}$ 477.2002, found 477.2002.

HPLC conditions: $(S, S)$-Whelk-O1, $n$-heptane/isopropanol/ dichloromethane 90/5/5, flow rate $=1.0 \mathrm{~mL} / \mathrm{min}$, UV $254 \mathrm{~nm}, \mathrm{t}_{\mathrm{R}}$ $(P)=6.98 \mathrm{~min}$ and $\mathrm{t}_{\mathrm{R}},(M)=8.14 \mathrm{~min} .(P)-\mathbf{1 0 a}: \mathrm{mp}=214{ }^{\circ} \mathrm{C} . e e=99.6 \%,[\alpha]_{D}^{23}=+2600\left( \pm 7 \%, \mathrm{CH}_{2} \mathrm{Cl}_{2}, 210^{-4} \mathrm{~mol}^{-\mathrm{L}^{-1}}\right) .(M)-$ 10a: $\mathrm{mp}=214{ }^{\circ} \mathrm{C} . e e=99.4 \%,[\alpha]_{D}^{23}=-2800\left( \pm 7 \%, \mathrm{CH}_{2} \mathrm{Cl}_{2}, 210^{-4} \mathrm{~mol} . \mathrm{L}^{-1}\right)$.

(1'S, 2'S, 3 'R, 5'S)-Pinanediol hexahelicen-2-ylboronic ester (10b). $124 \mathrm{mg}, 63 \%$. Yellowish solid. HPLC conditions for 10b1 and 10b2: Chiralpak IB, $n$-heptane/isopropanol 95/5, flow rate $=1.0 \mathrm{~mL} / \mathrm{min}, \mathrm{UV} 254 \mathrm{~nm}, \mathrm{t}_{\mathrm{R}}\left(\mathbf{1 0 b _ { 1 }}\right)=5.01$ and $\mathrm{t}_{\mathrm{R}}\left(\mathbf{1 0 b _ { 2 }}\right)=$ $4.40 \mathrm{~min}$.

10b1 could be also directly obtained by crystallization according to the following procedure. 43 mg of a 1/1 diastereomeric mixture of 10b1 and $\mathbf{1 0 b 2}$ was heated at reflux in $1 \mathrm{~mL}$ of $\mathrm{MeOH}$. After $10 \mathrm{mn}$, the mixture was cooled to room temperature and kept at this temperature for half an hour. $15 \mathrm{mg}$ of pure $\mathbf{1 0 b}$ (de $>99.5 \%$, measured by HPLC) was collected by filtration. Evaporation of the mother liquors afforded the diastereomerically enriched $\mathbf{1 0 b} 2$ with a de of $23 \%$. 
$(P)-10 b_{1}: \mathrm{mp}=196-198^{\circ} \mathrm{C} . \mathrm{R}_{\mathrm{f}}=0.33\left(\right.$ cyclohexane $\left./ \mathrm{CH}_{2} \mathrm{Cl}_{2}, 8 / 2\right) . d e=99.5 \%,{ }^{1} \mathrm{H}$ NMR $\left(400 \mathrm{MHz}, \mathrm{CD}_{2} \mathrm{Cl}_{2}\right) \delta 8.09-7.99(\mathrm{~m}$, $7 \mathrm{H}), 7.96(\mathrm{~d}, J=7.6 \mathrm{~Hz}, 1 \mathrm{H}), 7.90(\mathrm{~d}, J=9.0 \mathrm{~Hz}, 1 \mathrm{H}), 7.83(\mathrm{~d}, J=7.9 \mathrm{~Hz}, 1 \mathrm{H}), 7.74(\mathrm{dd}, J=8.0,1.3 \mathrm{~Hz}, 1 \mathrm{H}), 7.54(\mathrm{~d}, J=$ $7.7 \mathrm{~Hz}, 1 \mathrm{H}), 7.52(\mathrm{~d}, J=8.8 \mathrm{~Hz}, 1 \mathrm{H}), 7.18(\mathrm{~d}, J=8.0 \mathrm{~Hz}, 1 \mathrm{H}), 6.63(\mathrm{ddd}, J=8.4,6.8,1.3 \mathrm{~Hz}, 1 \mathrm{H}), 4.19(\mathrm{dd}, J=8.7,2.0 \mathrm{~Hz}$, $1 \mathrm{H}), 2.37-2.29(\mathrm{~m}, 1 \mathrm{H}), 2.26-2.08(\mathrm{~m}, 1 \mathrm{H}), 2.001 .98(\mathrm{~m}, 2 \mathrm{H}), 1.82(\mathrm{dt}, J=14.3,2.3 \mathrm{~Hz}, 1 \mathrm{H}), 1.34(\mathrm{~s}, 3 \mathrm{H}), 1.32(\mathrm{~s}, 3 \mathrm{H}), 1.02-$ $0.88(\mathrm{~m}, 1 \mathrm{H}), 0.85(\mathrm{~s}, 3 \mathrm{H}) .{ }^{13} \mathrm{C} \mathrm{NMR}\left(101 \mathrm{MHz}, \mathrm{CD}_{2} \mathrm{Cl}_{2}\right) \delta 136.3,134.1,133.8,132.7,131.84,131.79,130.7,130.3,129.3$, $128.7,128.6,128.41,128.35,128.2,128.1,127.9,127.7,127.5,127.4,127.2,126.7,125.9,125.0,124.5,86.6,78.5,52.0$, 40.1, 38.6, 35.7, 28.8, 27.4, 27.0, 24.3 (the carbon $\alpha$ to boron was not found). ${ }^{11} \mathrm{~B}$ NMR $\left(96 \mathrm{MHz}, \mathrm{CDCl}_{3}\right) \delta 30.2$. HRMS (ESI) $[\mathrm{M}+\mathrm{Na}]^{+}$calculated for $\mathrm{C}_{36} \mathrm{H}_{31} \mathrm{O}_{2} \mathrm{BNa} 529.2309$, found 529.2311. $[\alpha]_{D}^{23}=+2370,[\phi]_{D}^{23}=+11990\left( \pm 7 \%, \mathrm{CH}_{2} \mathrm{Cl}_{2}, 10^{-4}\right.$ mol. $\left.L^{-1}\right)$.

(M)-10b2: $\mathrm{mp}=88-90{ }^{\circ} \mathrm{C} . \mathrm{R}_{\mathrm{f}}=0.36\left(\right.$ cyclohexane $\left./ \mathrm{CH}_{2} \mathrm{Cl}_{2}, 8 / 2\right) . d e=99.5 \%,{ }^{1} \mathrm{H}$ NMR $\left(400 \mathrm{MHz}, \mathrm{CD}_{2} \mathrm{Cl}_{2}\right) \delta 8.07-7.90(\mathrm{~m}$, $9 \mathrm{H}), 7.83(\mathrm{~d}, J=7.9 \mathrm{~Hz}, 1 \mathrm{H}), 7.79(\mathrm{dd}, J=8.0,1.4 \mathrm{~Hz}, 1 \mathrm{H}), 7.55(\mathrm{dd}, J=8.0,1.1 \mathrm{~Hz}, 1 \mathrm{H}), 7.51(\mathrm{dd}, J=8.7,1.1 \mathrm{~Hz}, 1 \mathrm{H})$, 7.19 (ddd, $J=8.0,6.9,1.2 \mathrm{~Hz}, 1 \mathrm{H}), 6.63(\mathrm{ddd}, J=8.4,6.9,1.4 \mathrm{~Hz}, 1 \mathrm{H}), 4.24(\mathrm{dd}, J=8.7,2.0 \mathrm{~Hz}, 1 \mathrm{H}), 2.36-2.23(\mathrm{~m}, 2 \mathrm{H})$, $2.01(\mathrm{t}, J=5.6 \mathrm{~Hz}, 1 \mathrm{H}), 1.94-1.88(\mathrm{~m}, 1 \mathrm{H}), 1.76(\mathrm{ddd}, J=14.5,3.4,2.0 \mathrm{~Hz}, 1 \mathrm{H}), 1.37(\mathrm{~s}, 3 \mathrm{H}), 1.26(\mathrm{~s}, 3 \mathrm{H}), 0.89(\mathrm{~d}, J=11.0$ $\mathrm{Hz}, 1 \mathrm{H}), 0.85(\mathrm{~s}, 3 \mathrm{H}) .{ }^{13} \mathrm{C}$ NMR $\left(101 \mathrm{MHz}, \mathrm{CD}_{2} \mathrm{Cl}_{2}\right) \delta 136.0,134.1,133.7,132.8,131.79,131.77,130.7,130.2,129.5$, $128.7,128.6,128.44,128.39,128.2,128.0,127.9,127.7,127.44,127.36,127.2,126.5,125.7,124.9,124.5,86.2,78.7,52.0$, $40.2,38.7,35.9,28.9,27.5,27.4,24.3$ (the carbon $\alpha$ to boron was not found). ${ }^{11} \mathrm{~B}$ NMR $\left(96 \mathrm{MHz}, \mathrm{CDCl}_{3}\right) \delta 30.2$. HRMS (ESI) $[\mathrm{M}+\mathrm{Na}]^{+}$calculated for $\mathrm{C}_{36} \mathrm{H}_{31} \mathrm{O}_{2} \mathrm{BNa} 529.2309$, found 529.2312. $[\alpha]_{D}^{23}=-2640,[\phi]_{D}^{23}=-13360\left( \pm 7 \%, \mathrm{CH}_{2} \mathrm{Cl}_{2}, 10^{-4} \mathrm{~mol}^{2} \mathrm{~L}^{-}\right.$ ${ }^{1)}$.

( \pm )-Hexahelicen-2-ylboronic acid (10c). To a solution of [6] helicenylboronate $( \pm)-\mathbf{1 0 a}(30 \mathrm{mg}, 0.066 \mathrm{mmol}, 1 \mathrm{eq}$.) in a mixture of acetone $(4 \mathrm{~mL})$ and water $(2 \mathrm{~mL})$ were added sodium periodate $(85 \mathrm{mg}, 0.40 \mathrm{mmol}, 6$ eq. $)$ and ammonium acetate (31 mg, $0.40 \mathrm{mmol}, 6$ eq.). The solution was vigorously stirred at r.t for 4 days. The solvent was removed under vacuum and the resulting crude material was diluted with diethyl ether and washed with water. The organic layer was then dried over $\mathrm{MgSO}_{4}$ and concentrated under reduced pressure to give the boronic acid 10c as a brownish solid $(21 \mathrm{mg}, 84 \%)$. $\mathrm{mp}=134-$ $138^{\circ} \mathrm{C} . \mathrm{R}_{\mathrm{f}}=0.15$ (cyclohexane/ AcOEt, 7/3). ${ }^{1} \mathrm{H}$ NMR (300 MHz, DMSO-d $d_{6} \delta 8.21-7.95(\mathrm{~m}, 9 \mathrm{H}), 7.86(\mathrm{dd}, J=8.1,1.4 \mathrm{~Hz}$, $1 \mathrm{H}), 7.84(\mathrm{~d}, J=8.0 \mathrm{~Hz}, 1 \mathrm{H}), 7.61(\mathrm{dd}, J=7.9,1.1 \mathrm{~Hz}, 1 \mathrm{H}), 7.39(\mathrm{dd}, J=8.2,0.9 \mathrm{~Hz}, 1 \mathrm{H}), 7.39(\mathrm{~s}, 2 \mathrm{H}), 7.19$ (ddd, $J=8.0$, $6.9,1.1 \mathrm{~Hz}, 1 \mathrm{H}), 6.60$ (ddd, $J=8.4,6.9,1.4 \mathrm{~Hz}, 1 \mathrm{H}) .{ }^{13} \mathrm{C}$ NMR $(75 \mathrm{MHz}$, DMSO-d $) \delta 134.1,132.7,132.4,131.7,130.9$, 130.7, 130.5, 129.0, 128.5, 128.0, 127.8, 127.7 (2C), 127.5, 127.4, 127.2, 126.8 (2C), 126.7, 126.6, 126.1, 125.4, 124.3, 123.1 (the carbon $\alpha$ to boron was not found). ${ }^{11} \mathrm{~B}$ NMR $\left(96 \mathrm{MHz}, \mathrm{CDCl}_{3}\right) \delta 30.4$.

(M)-2-Aminohexahelicene (12). To a solution of $\mathrm{NaN}_{3}\left(55 \mathrm{mg}, 0.84 \mathrm{mmol}, 2.6\right.$ eq.) and $\mathrm{CuSO}_{4} .5 \mathrm{H}_{2} \mathrm{O}(3 \mathrm{mg}, 0.010 \mathrm{mmol}$, 0.23 eq.) in $\mathrm{MeOH}(1.5 \mathrm{~mL})$ was added the boronate $(M)-10 \mathrm{a}(20 \mathrm{mg}, 0.044 \mathrm{mmol}, 1$ eq.). The solution was vigorously stirred at reflux for 19h. After evaporation of $\mathrm{MeOH}$, EtOAc $(2 \mathrm{~mL})$ and $10 \% \mathrm{Pd} / \mathrm{C}(8 \mathrm{mg})$ were added. A balloon filled with dihydrogen gas under atmospheric pressure was adapted to the reaction vessel through a needle. The solution was first purged by three cycles of vacuum and dihydrogen, refilling, then flushed again with the dihydrogen. After stirring overnight, the solvent was removed under vacuum and the residue was subjected to chromatography (silica gel, cyclohexane/ $\mathrm{CH}_{2} \mathrm{Cl}_{2}$, $7 / 3$ as eluent) to afford the amino derivative $(M)-12$. (12 mg, $75 \%)$. Yellowish solid, $\mathrm{mp}=195-197{ }^{\circ} \mathrm{C} . \mathrm{R}_{\mathrm{f}}=0.10$ (cyclohexane/ $\left.\mathrm{CH}_{2} \mathrm{Cl}_{2}, 7 / 3\right) .{ }^{1} \mathrm{H}$ NMR $\left(400 \mathrm{MHz}, \mathrm{CDCl}_{3}\right) \delta$ 8.03-7.91 (m, 6H), 7.89-7.78 (m, 2H), $7.75(\mathrm{~d}, J=8.6 \mathrm{~Hz}, 1 \mathrm{H})$, $7.71(\mathrm{~d}, J=8.5 \mathrm{~Hz}, 1 \mathrm{H}), 7.65(\mathrm{~d}, J=8.4 \mathrm{~Hz}, 1 \mathrm{H}), 7.32(\mathrm{ddd}, J=8.0,6.8,1.2 \mathrm{~Hz}, 1 \mathrm{H}), 6.82(\mathrm{~d}, J=2.3 \mathrm{~Hz}, 1 \mathrm{H}), 6.79(\mathrm{ddd}, J$ $=8.5,6.9,1.5 \mathrm{~Hz}, 1 \mathrm{H}), 6.67(\mathrm{dd}, J=8.4,2.3 \mathrm{~Hz}, 1 \mathrm{H}), 3.00(\mathrm{br}, 2 \mathrm{H}) .{ }^{13} \mathrm{C} \mathrm{NMR}\left(101 \mathrm{MHz}, \mathrm{CDCl}_{3}\right) \delta 144.0,133.0,132.2$, 131.7, 131.4, 131.3, 130.4, 129.0, 127.9, 127.8, 127.7, 127.6, 127.4, 127.3, 127.1, 126.93, 126.86, 126.8, 126.5, 126.0, 125.9, $124.7,124.5,122.8,116.3,111.8$. HRMS (ESI) $[\mathrm{M}+\mathrm{H}]^{+}$calculated for $\mathrm{C}_{26} \mathrm{H}_{18} \mathrm{~N} 344.1439$, found 344.1434. $[\alpha]_{D}^{23}=-3210,[\phi]_{D}^{23}$ $=-11020\left( \pm 7 \%, \mathrm{CH}_{2} \mathrm{Cl}_{2}, 2.8510^{-4} \mathrm{~mol} \cdot \mathrm{L}^{-1}\right)$.

Similarly, the $(P)-\mathbf{1 2}$ enantiomer could be prepared starting from enantiopure isomer $(P)$-10a. $(P)-\mathbf{1 2}:[\alpha]_{D}^{23}=+2990$, $[\phi]_{D}^{23}=$ $+10270\left( \pm 7 \%, \mathrm{CH}_{2} \mathrm{Cl}_{2}, 3.010^{-4} \mathrm{~mol} \cdot \mathrm{L}^{-1}\right)$.

(M)-2-(N-Benzylamino)hexahelicene (13). In a Schlenk tube equipped with a septum under argon were introduced $(M)$-10a (20 mg, $0.044 \mathrm{mmol}, 1$ eq.) and $\mathrm{CH}_{2} \mathrm{Cl}_{2}(0.5 \mathrm{~mL})$. Boron trichloride (1M solution in hexane, $0.22 \mathrm{~mL}, 0.22 \mathrm{mmol}, 5$ eq.) was then added at $0^{\circ} \mathrm{C}$. After $3 \mathrm{~h}$ at r.t, the solvent and the excess of $\mathrm{BCl}_{3}$ were removed under vacuum and the residue was taken up with $\mathrm{CH}_{2} \mathrm{Cl}_{2}(0.5 \mathrm{~mL})$ and benzyl azide $(17 \mu \mathrm{L}, 0.13 \mathrm{mmol}, 3$ eq. $)$ at $0^{\circ} \mathrm{C}$. After $17 \mathrm{~h}$ at r.t., AcOEt $(10 \mathrm{~mL})$ and $2 \mathrm{~N} \mathrm{NaOH}$ $(0.5 \mathrm{~mL})$ were successively added. The organic layer was separated, dried over $\mathrm{MgSO}_{4}$ and concentrated under reduced pressure. The crude product was purified by chromatography (silica gel, cyclohexane/ $\mathrm{CH}_{2} \mathrm{Cl}_{2}: 6 / 4$ as eluent) to give $\mathbf{1 3}$ as a yellow oil (13 mg, $68 \%$ ). $\mathrm{R}_{\mathrm{f}}=0.60$ (cyclohexane/ $\left.\mathrm{CH}_{2} \mathrm{Cl}_{2}, 5 / 5\right) .{ }^{1} \mathrm{H} \mathrm{NMR}\left(400 \mathrm{MHz}, \mathrm{CDCl}_{3}\right) \delta 8.01-7.89(\mathrm{~m}, 6 \mathrm{H}), 7.89(\mathrm{dd}$, 
$J=8.0,1.3 \mathrm{~Hz}, 1 \mathrm{H}), 7.81(\mathrm{~d}, J=8.4 \mathrm{~Hz}, 1 \mathrm{H}), 7.77(\mathrm{dd}, J=8.6,1.0 \mathrm{~Hz}, 1 \mathrm{H}), 7.71(\mathrm{~d}, J=8.4 \mathrm{~Hz}, 1 \mathrm{H}), 7.64(\mathrm{~d}, J=8.6 \mathrm{~Hz}$, $1 \mathrm{H}), 7.34(\mathrm{ddd}, J=7.9,6.8,1.2 \mathrm{~Hz}, 1 \mathrm{H}), 7.28-7.17(\mathrm{~m}, 3 \mathrm{H}), 7.02(\mathrm{~d}, J=8.0 \mathrm{~Hz}, 2 \mathrm{H}), 6.81$ (ddd, $J=8.4,6.8,1.4 \mathrm{~Hz}, 1 \mathrm{H})$, $6.76(\mathrm{~d}, J=2.3 \mathrm{~Hz}, 1 \mathrm{H}), 6.63(\mathrm{dd}, J=8.6,2.3 \mathrm{~Hz}, 1 \mathrm{H}), 3.54(\mathrm{br}, 1 \mathrm{H}), 3.39(\mathrm{~d}, J=13.5 \mathrm{~Hz}, 1 \mathrm{H}), 3.34(\mathrm{~d}, J=13.5 \mathrm{~Hz}, 1 \mathrm{H})$. ${ }^{13} \mathrm{C}$ NMR $\left(101 \mathrm{MHz}, \mathrm{CDCl}_{3}\right) \delta 145.7,139.1,133.1,132.3,131.7,131.6,131.3,130.7,128.8,128.5$ (2C), 127.93, 127.89, 127.8 (2C), 127.7, 127.5, 127.3, 127.2, 127.14, 127.10, 126.8 (2C), 125.9, 125.4, 124.8, 124.6, 122.3, 115.9, 107.9, 47.7. HRMS (ESI) $[\mathrm{M}+\mathrm{Na}]^{+}$calculated for $\mathrm{C}_{33} \mathrm{H}_{23} \mathrm{NNa} 456.1728$, found 456.1725. $[\alpha]_{D}^{23}=-3260,[\phi]_{D}^{23}=-14150\left( \pm 7 \%, \mathrm{CH}_{2} \mathrm{Cl}_{2}, 2.3\right.$ $10^{-4}$ mol.L $\left.\mathrm{L}^{-1}\right)$.

(M)-2-(Piperidin-1-yl)hexahelicene (14). (M)-10a (20 mg, $0.044 \mathrm{mmol}, 1$ eq.), powdered activated $4 \AA$ molecular sieves (15 $\mathrm{mg}), \mathrm{Cu}(\mathrm{OAc})_{2}(10 \mathrm{mg}, 0.055 \mathrm{mmol}, 1,25$ eq. $), \mathrm{B}(\mathrm{OH})_{3}(8 \mathrm{mg}, 0.13 \mathrm{mmol}, 2.94$ eq. $)$, and piperidine $(9 \mu \mathrm{L}, 0.088 \mathrm{mmol}, 2.00$ eq.) in $\mathrm{MeCN}\left(0,2 \mathrm{~mL}\right.$ ) were sealed in an Ace pressure tube under air and stirred at $80{ }^{\circ} \mathrm{C}$ (preheated sand bath, sand temperature) for $26 \mathrm{~h}$. The reaction mixture was allowed to reach to room temperature, filtered through Celite. The filtrate was concentrated under vacuum and the residue was purified by flash chromatography (cyclohexane $/ \mathrm{CH}_{2} \mathrm{Cl}_{2}, 8 / 2$ as eluent) to give 14 as a yellowish solid $(8 \mathrm{mg}, 44 \%) . \mathrm{mp}=44-48{ }^{\circ} \mathrm{C}$. $\mathrm{R}_{\mathrm{f}}=0.30\left(\right.$ cyclohexane $\left./ \mathrm{CH}_{2} \mathrm{Cl}_{2}, 5 / 5\right) .{ }^{1} \mathrm{H} \mathrm{NMR}(400 \mathrm{MHz}$, $\left.\mathrm{CDCl}_{3}\right) \delta$ 8.04-7.92 (m, 5H), $7.88(\mathrm{~d}, J=8.6 \mathrm{~Hz}, 1 \mathrm{H}), 7.85-7.80(\mathrm{~m}, 2 \mathrm{H}), 7.77(\mathrm{~d}, J=8.4 \mathrm{~Hz}, 1 \mathrm{H}), 7.72(\mathrm{~d}, J=4.0 \mathrm{~Hz}, 1 \mathrm{H})$, $7.70(\mathrm{~d}, J=4.2 \mathrm{~Hz}, 1 \mathrm{H}), 7.26(\mathrm{ddd}, J=8.4,6.9,1.2 \mathrm{~Hz}, 1 \mathrm{H}), 7.05(\mathrm{~s}, 1 \mathrm{H}), 6.99(\mathrm{~d}, J=8.8 \mathrm{~Hz}, 1 \mathrm{H}), 6.75(\mathrm{ddd}, J=8.4,6.9$, $1.4 \mathrm{~Hz}, 1 \mathrm{H}), 2.45-2.38(\mathrm{~m}, 2 \mathrm{H}), 2.33-2.22(\mathrm{~m}, 2 \mathrm{H}), 1.45-1.34(\mathrm{~m}, 6 \mathrm{H}) .{ }^{13} \mathrm{C}$ NMR $\left(101 \mathrm{MHz}, \mathrm{CDCl}_{3}\right) \delta 150.0,133.2,132.0$, 131.3, 131.1, 130.3, 128.3, 128.0, 127.8, 127.7 (2C), 127.6 (2C), 127.4, 127.3, 127.1, 127.0, 126.8 (2C), 126.4, 126.0, 125.0, 124.4, 123.5, 119.1, 113.4, 50.7, 25.8, 24.2. HRMS (ESI) $[\mathrm{M}+\mathrm{Na}]^{+}$calculated for $\mathrm{C}_{31} \mathrm{H}_{25} \mathrm{NNa} 434.1885$, found 434.1878. $[\alpha]_{D}^{p_{3}^{3}}$ $=-2600,[\phi]_{D}^{23}=-10360\left( \pm 7 \%, \mathrm{CH}_{2} \mathrm{Cl}_{2}, 2.010^{-4} \mathrm{~mol} \cdot \mathrm{L}^{-1}\right)$.

Similarly, the $(P)$-14 enantiomer could be prepared starting from enantiopure isomer $(P)$-10a. $(P)-\mathbf{1 4}:[\alpha]_{D}^{23}=+2430,[\phi]_{D}^{23}=$ $+9685\left( \pm 7 \%, \mathrm{CH}_{2} \mathrm{Cl}_{2}, 2.110^{-4}\right.$ mol.L $\left.{ }^{-1}\right)$.

$(M, R)$ - and (M,S)-Methyl-2-(hexahelicen-2-yl)-2-morpholinoacetate 15. (M)-10a (40 mg, $0.088 \mathrm{mmol}, 1$ eq.), morpholine ( $22 \mu \mathrm{L}, 0.26 \mathrm{mmol}, 3$ eq.), and glyoxylic acid monohydrate $(24 \mathrm{mg}, 0.26 \mathrm{mmol}, 3$ eq.) in 1,1,1,3,3,3-hexafluoro-2-propanol $(2 \mathrm{~mL})$ were sealed in an Ace pressure tube under air and stirred at $60{ }^{\circ} \mathrm{C}$ for $48 \mathrm{~h}$. The reaction mixture was allowed to cool down to room temperature, and concentrated under vacuum. THF $(1 \mathrm{~mL}), \mathrm{MeOH}(0,5 \mathrm{~mL})$ and (trimethylsilyl)diazomethane solution ( $2 \mathrm{M}$ in diethyl ether) $(0,13 \mathrm{~mL}, 0.26 \mathrm{mmol}, 3 \mathrm{eq}$.) were then successively added. After $20 \mathrm{~h}$ at r.t and concentration under reduced pressure, the residue ( $7 / 3$ mixture of two diastereomers) was purified by flash chromatography (cyclohexane/AcOEt : 9/1 as eluent) to give the two diastereomers $(M)-\mathbf{1 5}(42 \mathrm{mg}, 84 \%)$.

Major isomer $(M, R)-\mathbf{1 5 a}: 29 \mathrm{mg}, \mathrm{mp}=107-11{ }^{\circ} \mathrm{C}$ (decomp.). $\mathrm{R}_{\mathrm{f}}=0.30$ (cyclohexane/AcOEt, 7/3). ${ }^{1} \mathrm{H} \mathrm{NMR}(400 \mathrm{MHz}$, $\left.\mathrm{CDCl}_{3}\right) \delta 8.03-7.94(\mathrm{~m}, 7 \mathrm{H}), 7.91(\mathrm{~d}, J=8.5 \mathrm{~Hz}, 1 \mathrm{H}), 7.87-7.83(\mathrm{~m}, 2 \mathrm{H}), 7.61(\mathrm{~d}, J=8.6 \mathrm{~Hz}, 1 \mathrm{H}), 7.59-7.55(\mathrm{~m}, 2 \mathrm{H}), 7.16$ (ddd, $J=8.0,6.8,1.2 \mathrm{~Hz}, 1 \mathrm{H}), 6.69$ (ddd, $J=8.4,6.8,1.5 \mathrm{~Hz}, 1 \mathrm{H}), 3.80-3.58(\mathrm{~m}, 4 \mathrm{H}), 3.35(\mathrm{~s}, 3 \mathrm{H}), 3.05(\mathrm{~s}, 1 \mathrm{H}), 1.99-1.75$ $(\mathrm{m}, 4 \mathrm{H}) .{ }^{13} \mathrm{C}$ NMR $\left(101 \mathrm{MHz}, \mathrm{CDCl}_{3}\right) \delta 171.4,133.4,132.8,132.3,132.1,131.6,131.5,130.2,130.0,129.7,128.7,128.14$, $128.11,128.0,127.8,127.7,127.6,127.3,127.2,127.0,126.9,126.7,125.5,125.0,124.0,75.4,66.8,52.0$. HRMS (ESI) $[\mathrm{M}+\mathrm{Na}]^{+}$calculated for $\mathrm{C}_{33} \mathrm{H}_{27} \mathrm{NO}_{3} \mathrm{Na} 508.1889$, found 508.1884. $[\alpha]_{D}^{23}=-2490,[\phi]_{D}^{23}=-12070\left( \pm 7 \%, \mathrm{CH}_{2} \mathrm{Cl}_{2}, 3.710^{-4}\right.$ mol.L $1)$.

Minor Isomer $(M, S)-\mathbf{1 5 b}: 13 \mathrm{mg}, \mathrm{mp}=103-107{ }^{\circ} \mathrm{C}$ (decomp). $\mathrm{R}_{\mathrm{f}}=0.35$ (cyclohexane/AcOEt, 7/3). ${ }^{1} \mathrm{H} \mathrm{NMR}(400 \mathrm{MHz}$, $\left.\mathrm{CDCl}_{3}\right) \delta 8.03-7.94(\mathrm{~m}, 7 \mathrm{H}), 7.91(\mathrm{~d}, J=8.5 \mathrm{~Hz}, 1 \mathrm{H}), 7.84(\mathrm{~d}, J=8.1 \mathrm{~Hz}, 1 \mathrm{H}), 7.82(\mathrm{dd}, J=7.9,1.3 \mathrm{~Hz}, 1 \mathrm{H}), 7.60-7.57(\mathrm{~m}$, $2 \mathrm{H}), 7.44(\mathrm{dd}, J=8.3,1.7 \mathrm{~Hz}, 1 \mathrm{H}), 7.18(\mathrm{ddd}, J=8.0,6.9,1.1 \mathrm{~Hz}, 1 \mathrm{H}), 6.67(\mathrm{ddd}, J=8.4,6.8,1.4 \mathrm{~Hz}, 1 \mathrm{H}), 3.52(\mathrm{~s}, 3 \mathrm{H})$, $3.51-3.43(\mathrm{~m}, 4 \mathrm{H}), 3.42(\mathrm{~s}, 1 \mathrm{H}), 2.00-1.96(\mathrm{~m}, 4 \mathrm{H}) .{ }^{13} \mathrm{C}$ NMR $\left(101 \mathrm{MHz}, \mathrm{CDCl}_{3}\right) \delta 171.4,133.3,132.5,132.3,131.7,131.5$, $130.1,129.8,128.5,128.32,128.26,128.14,128.12$, 128.0, 127.7, 127.6, 127.4, 127.3, 127.2, 126.9, 126.8, 126.4, 125.9, $125.5,124.9,124.1,73.8,67.0$,

51.9, 50.9. HRMS (ESI) $[\mathrm{M}+\mathrm{Na}]^{+}$calculated for $\mathrm{C}_{33} \mathrm{H}_{27} \mathrm{NO}_{3} \mathrm{Na} 508.1889$, found 508.1884. $[\alpha]_{D}^{23}=-2290$, $[\phi]_{D}^{23}=-11100$ $\left( \pm 7 \%, \mathrm{CH}_{2} \mathrm{Cl}_{2}, 1.910^{-4} \mathrm{~mol} \cdot \mathrm{L}^{-1}\right)$.

\section{ASSOCIATED CONTENT}

\section{Supporting Information}

${ }^{1} \mathrm{H},{ }^{13} \mathrm{C}$ and ${ }^{11} \mathrm{~B}$ spectra of compounds 9a, 9b, 10a, $(P)-10 b_{1},(M)-10 b_{2}, 10 c,(M)-12(M)-13,(M)-14$ and $(M)$-15; X-ray diffraction data of $(M)-\mathbf{1 0 a},(P)-\mathbf{1 0 b} \mathbf{b}_{1}$ and $(M, S)-\mathbf{1 5} \mathbf{b}$; HPLC conditions for compounds 10a and 10b. This material is available free of charge on the ACS Publications website at DOI:

\section{AUTHOR INFORMATION}




\section{Corresponding Authors}

* jeanne.crassous@univ-rennes1.fr

* bertrand.carboni@univ-rennes1.fr

\section{ORCID}

Jeanne Crassous: 0000-0002-4037-6067X

Bertrand Carboni: 0000-0003-0529-715X

\section{Notes}

The authors declare no competing financial interest.

\section{ACKNOWLEDGMENTS}

We acknowledge the Ministère de l'Education Nationale, de la Recherche et de la Technologie, the Centre National de la Recherche Scientifique (CNRS), the CNRS (Chirafun network), and the ANR (12-BS07-0004-METALHEL-01), for financial support.

\section{REFERENCES}

(1) Selected recent reviews: (a) Helicene Chemistry - From Synthesis to Applications, Chen, C. -F.; Shen, Y., Ed.; Springer, 2017. (b) Saleh, N.; Shen, C.; Crassous, J. Chem. Sci. 2014, 5, 3680-3694. (c) Bosson, J.; Gouin, J.; Lacour, J. Chem. Soc. Rev. 2014, 43, 2824-2840. (d) Gingras, M. Chem. Soc. Rev. 2013, 42, 1051-1095. (e) Shen, Y.; Chen, C. -F. Chem. Rev. 2012, 112, 1463-1535. (f) Amemiya, R.; Yamaguchi, M. Chem. Rec. 2008, 8, 116-127.

(2) For recent reviews, see: (a) Narcis, M. J.; Takenaka, N. Eur. J. Org. Chem. 2014, 21-34. (b) Aillard, P.; Voituriez, A.; Marinetti, A. Dalton Trans. 2014, 43, 15263-15278. (c) Peng, Z., Takenaka, N. Chem. Rec. 2013, 13, 28-42.

(3) Selected examples: (a) Josse, P.; Favereau, L.; Shen, C.; Dabos-Seignon, S.; Blanchard, P.; Cabanetos, C.; Crassous, J. Chem. Eur. J. 2017, 23, 6277-6281. (b) Brandt, J. R.; Wang, X.-H.; Yang, Y.; Campbell, A.; Fuchter M. J. J. Am. Chem. Soc. 2016, 138, 9743-9746. (c) Yang, Y.; Correa da Costa, R.; Fuchter, M. J.; Campbell, A. J. Nature Photonics 2013, 7, 634-638. (d) See review: Brandt, J. R.; Salerno, F.; Fuchter, M. J. Nature Rev. Chem. 2017, 1, 0045 and references therein.

(4) Recent examples: (a) Fontana, F.; Melone, F.; Iannazzo, D.; Leonardi, S. G.; Neri, G. Nanotechnology, 2017, 28, 135501-135510. (b) Hasan, M.; Khose, V. N.; Mori, T.; Borovkov, V.; Karnik, A. V. ACS Omega 2017, 2, 592-598. (c) Tounsi, M.; Ben Braiek, M.; Baraket, A.; Lee, M.; Zine, N.; Zabala, M.; Bausells, J.; Aloui, F.; Ben Hassine, B.; Maaref, A.; Errachid, A. Electroanalysis 2016, 28, 2892-2899. (d) Huang, Q.; Jiang, L.; Liang, W.; Gui, J.; Xu, D.; Wu, W.; Nakai, Y.; Nishijima, M.; Fukuhara, G.; Mori, T.; Inoue, Y.; Yang, C. J. Org. Chem., 2016, 81, 3430-3434.

(5) (a) Brandt, J. R.; Pospsisil, L.; Bednarova, L.; Correa da Costa, R.; White, A. J. P.; Mori, T.; Teply, F.; Fuchter, M. J. Chem. Comm. 2017, 53, 9059-9062. (b) Shen, C.; He, X.; Toupet, L.; Norel, L.; Rigaut, S.; Crassous J. Organometallics 2017, doi:10.1021/acs.organomet.7b00534. (c) Shen, C.; Loas, G.; Srebro-Hooper, M.; Vanthuyne, N.; Toupet, L.; Cador, O.; Paul, F.; López Navarrete, J. T.; Ramírez, F. J.; Nieto-Ortega, B.; Casado, J.; Autschbach, J.; Vallet, M.; J. Crassous, Angew. Chem. Int. Ed. 2016, 55, 8062-8066. (d) Pascal, S.; Besnard, C.; Zinna, F.; Di Bari, L.; Le Guennic, B.; Jacquemin, D.; Lacour, J. Org. Biomol. Chem. 2016, 14, 4590-4594. (e) See review: Isla, H.; Crassous, J. C. R. Chim. 2016, 19, 39-49 and references therein.

(6) (a) Sanchez, I. G.; Samal, M.; Nejedly, J.; Karras, M.; Klivar, J.; Rybacek, J.; Budesinsky, M.; Bednarova, L.; Seidlerova, B.; Stara, I. G.; Stary, I. Chem. Commun. 2017, 53, 4370-4373. (b) Hernandez Delgado, I.; Pascal, S.; Wallabregue, A.; Duwald, R.; Besnard, C.; Guénée, L.; Nançoz, C.; Vauthey, E.; Tovar, R. C.; Lunkley, J. L.; Muller, G.; Lacour, J. Chem. Sci. 2016, 7, 4685-4693. (c) van der Meijden, M. W.; Gelens, E.; Murillo Quiros, N.; Fuhr, J. D.; Gayone, J. E.; Ascolani, H.; Wurst, K.; Lingenfelder, M.; Kellogg, R. M. Chem. Eur. J. 2016, 22, 1484-1492. (d) Ascolani, H.; van der Meijden, M. W.; Cristina, L. J.; Gayone, J. E.; Kellogg, R. M.; Fuhr, J. D.; Lingenfelder, M. Chem. Commun. 2014, 50, 13907-13090. (e) Pieters, G.; Gaucher, A.; Prim, D.; Marrot, J. Chem. Commun. 2009, 4827-4828. (f) Teplý, F.; Stará, I. G.; Starý, I.; Kollárovic, A.; Šaman, D.; Vyskočil, S.; Fiedler, P. J. Org. Chem. 2003, 68, 5193-5197. (g) Okubo, H.; Nakano, D.; Anzai, S.; Yamaguchi, M. J. Org. Chem. 2001, 66, 557-563. (h) For an amino[7]helicene see: Zadny, J.; Velísek, P.; Jakubec, M.; Sykora, J.; Církva, V.; Storch, J. Tetrahedron 2013, 69, 6213-6218.

(7) Kushida, Y.; Sawato, T.; Shigeno, M.; Saito, N.; Yamaguchi, M. Chem. Eur. J. 2017, 23, 327-333.

(8) (a) Boron reagents in synthesis; Coca, A. Eds, ACS Symposium Series 1236; American Chemical Society: Washington, DC, 2016. (b) Boronic acids: Preparation, Applications in Organic Synthesis and Medicine, 2nd ed.; Hall, D. G., Ed.; Wiley-VCH: Weinheim, Germany, 2011.

(9) If boronic esters have been used on numerous occasions as intermediates in the synthesis of helicenes, they were not hitherto used as direct precursors of the corresponding amino derivatives. For some references, see: (a) Yavari, K.; Aillard, P.; Zhang, Y.; Nuter, F.; Retailleau, P.; Voituriez, A.; Marinetti, A. Angew. Chem. Int. Ed. 2014, 53, 861-865. (b) Bédard, A.-C.; Vlassova, A.; Hernandez-Perez, A. C.; Bessette, A.; Hanan, G. S.; Heuft, M. A.; Collins, S. K. Chem. Eur. J. 2013, 19, 16295-16302. (c) Yavari, K.; Moussa, S; Hassine, B. B.; Retailleau, P.; Voituriez, A.; Marinetti, A. Angew. Chem. Int. Ed. 2012, 51, 6748-6752. (d) Shimizu, M; Nagao, I; Tomioka, Y.; Kadowaki, T.; Hiyama, T. Tetrahedron 2011, 67, 8014-8026.

(10) (a) Nakai, Y.; Mori, T.; Inoue, Y. J. Phys. Chem. A 2012, 116, 7372-7385. (b) Knowles, J. P.; Elliott, L. D.; Booker-Milburn, K. I. Beilstein J. Org. Chem. 2012, 8, 2025-2052. (c) Lightner, D. A.; Hefelfinger, D. T.; Powers, T. W.; Frank, G. W.; Trueblood, K. N.; D. J. Am. Chem. Soc. 1972, 94, 3492-3497. (d) Newman, M.S.; Lednicer, D. J. Am. Chem. Soc. 1956, 78, 4765-4770.

(11) Ban, H.S.; Usui, T.; Nabeyama, W.; Morita, H.; Fukuzawa, K.; Nakamura, H. Org. Biomol. Chem. 2009, 7, 4415-4427.

(12) Another approach involving an iridium-catalyzed borylation of the parent carbo[6]helicene was also tested. This strategy was successfully implemented with [4]helicene very recently. See: Necas, D.; Kaiser, R. P.; Ulc, J. Eur. J. Org. Chem. 2016, 5647-5652. Concerning the [6]helicene analogue, in our hands, borylation actually occurred regioselectively at the 3-position, but with a modest yield and unsatisfactory purity, which implies further optimization to be synthetically useful. 
(13) Lipshutz, B. H.; Boskovic, Z. V.; Aue D. H. Angew. Chem. Int. Ed. 2008, 47, 10183-10186.

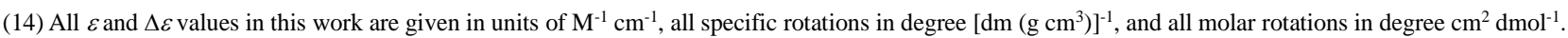

(15) Selected examples: (a) Gingras, M.; Felix, G.; Peresutti, R. Chem. Soc. Rev. 2013, 42, 1007-1050. (b) Weimar, M.; Correa da Costa, R.; Lee, F.-H.; Fuchter, M. J. Org. Lett. 2013, 15, 1706-1709. (c) Heller, B.; Hapke, M.; Fischer, C.; Andronova, A.; Stary, I.; Stara, I. G. J. Organomet. Chem. 2013, 723, 98-102 and references therein. (d) Sawada, Y.; Furumi, S.; Takai, A.; Takeuchi, M.; Noguchi, K.; Tanaka, K.; J. Am. Chem. Soc. 2012, 134, 4080-4083. (e) Zadny, J.; Jancarik, A.; Andronova, A.; Samal, M.; Chocholousova, J.V.; Vacek, J.; Pohl, R.; Saman, D.; Cisarova, I.; Stara, I. G.; Stary, I. Angew. Chem. Int. Ed. 2012, 51, 5857-5861. (f) Latorre, A.; Urbano, A.; Carreno, M. C.; Chem. Commun. 2011, 47, 8103-8105. (g) Laleu, B.; Mobian, P.; Herse, C.; Laursen, B. W.; Hopfgartner, G.; Bernardinelli, G.; Lacour, J. Angew. Chem. Int. Ed. 2005, 44, 1879-1883.

(16) (a) Enantiomers, Racemates, and Resolutions, Jacques, J.; Collet A.; Wilen, S. H., Eds.; Krieger, Malabar, Florida, 2nd ed., 1994. (b) Vavra, J.; Severa, L.; Cisarova, I.; Klepetarova, B.; Saman, D.; Koval, D.; Kasicka, V.; Teply, F. J. Org. Chem., 2013, 78, 1329-1342 and references therein. (c) Vavra, J.; Severa, L.; Svec, P.; Cisarova, I.; Koval, D.; Sazelova, P.; Kasicka, V.; Teply, F. Eur. J. Org. Chem., 2012, 489-499. (d) Paruch, K.; Katz, T.J.; Incarvito, C.; Lam, K- C.; Rhatigan, B.; Rheingold, A. L. J. Org. Chem., 2000, 65, 7602-7608. (e) Bensalah-Ledoux, A.; Pitrat, D.; Reynaldo, T.; Srebro-Hooper, M.; Moore II,, B.; Autschbach, J.; Crassous, J.; Guy, S.; Guy, L. Chem. Eur. J. 2016, 22, 3333-3346.

(17) CCDC 1579151,1573419 and 1579161 contain the supplementary crystallographic data for $(M)$-10a, 10b $\mathbf{1}$ and $\mathbf{1 5 b}$, respectively. These data can be obtained free of charge from Cambridge Crystallographic Data Centre via www.ccdc.cam.ac.uk/data_request/cif.

(18) Voth, S., Hollett, J.W., McCubbin, J.A. J. Org. Chem. 2015, 80, 2545-2553.

(19) Mlynarski, S. N.; Karns, A. S.; Morken, J. P. J. Am. Chem. Soc. 2012, 134, 16449-16451.

(20) Grimes, K. D.; Gupte, A.; Aldrich, C. C. Synthesis 2010, 1441-1448. Copper sulfate was preferred to copper acetate to minimize side products.

(21) Jego, J. M.; Carboni, B.; Vaultier, M.; Carrié R. J. Chem. Soc., Chem. Commun. 1989, 142-143.

(22) Vantourout, J. C.; Miras, H. N.; Isidro-Llobet, A.; Sproules, S.; Watson, A. J. B. J. Am. Chem. Soc. 2017, 139, 4769-4779

(23) For recent reviews on the Petasis three-component coupling reaction, see: (a) Carboni, B.; Berrée, F. In Science of Synthesis: Multicomponent Reactions; Müller, T. J. G., Ed; Thieme: New York, 2013; Vol 5, pp 219-259. (b) Batey, R. A. In Boronic Acids: Preparation and Applications in Organic Synthesis, Medicine and Materials, 2nd ed.; Hall, D. G., Ed.; Wiley-VCH: Weinheim, Germany, 2011; pp 427-477. (c) Candeias, N. R.; Montalbano, F.; Cal, P. M. S. D.; Gois, P. M. P. Chem. Rev. 2010, 110, 6169-6193. 